\title{
The Feminization of Occupations and Change in Wages: A Panel Analysis of Britain, Germany, and Switzerland
}

\author{
Emily Murphy, LIVES - Swiss National Centre of Competence in Research, University \\ of Zurich, Jacobs Center for Productive Youth Development \\ Daniel Oesch, LIVES - Swiss National Centre of Competence in Research, Life Course \\ and Inequality Research Centre (LINES), University of Lausanne
}

$\mathrm{n}$ the past four decades, women have made major inroads into occupations previously dominated by men. This paper examines whether occupational feminization is accompanied by a decline in wages: Do workers suffer a wage penalty if they remain in, or move into, feminizing occupations? We analyze this question over the 1990s and 2000s in Britain, Germany, and Switzerland, using longitudinal panel data to estimate individual fixed effects for men and women. Moving from an entirely male to an entirely female occupation entails a loss in individual earnings of 13 percent in Britain, 7 percent in Switzerland, and 3 percent in Germany. The impact of occupational feminization on wages is not linear, but sets apart occupations holding more than 60 percent of women. Moving into such female occupations incurs a wage penalty. Contrary to the prevailing idea in economics, differences in productivity - human capital, job-specific skills, and time investment-do not fully explain the wage gap between male and female occupations. The wage penalty associated with working in a female occupation is also much larger where employer discretion is greater - in the private sector-than where wagesetting is guided by formal rules - the public sector. These findings suggest that wage disparities across male and female occupations are due to gender devaluation.

\section{Introduction}

Over the past four decades, women's labor-market participation has increased continuously in the Western world. The growing number of employed women has thus led to a series of occupations becoming more "female." Professions in healthcare, law, and human resources are examples of higher-level occupations in which women have greatly increased their employment share. Postal clerks and bakers represent lower-level occupations that have feminized.

This paper was written at Switzerland's National Centre of Competence in Research, "LIVES-Overcoming Vulnerability: Life Course" and funded by the Swiss National Science Foundation. The financial support is gratefully acknowledged. We greatly benefited from the comments made by Fabrizio Bernardi, Marlis Buchmann, Felix Bühlmann, Rafael Lalive, and Kim Weeden. 
The question raised in this paper is whether occupational feminization is accompanied by a decline in wages. At the aggregate level, the concern is whether increasingly female jobs such as physicians, teachers, or social workers lose ground in the occupational earnings hierarchy. At the individual level, the issue at stake is whether workers who remain in, or move into, feminizing occupations suffer a wage penalty.

In the literature, several views have challenged each other over this question. One view is based on neoclassical economics and stresses differential investment into skill acquisition and paid work between male- and female-dominated occupations (e.g., Becker 1985; Tam 1997; Polavieja 2008, 2012). This argument expects employers to pay lower wages in female occupations on a rational basis; productivity in these occupations is lower, as workers accumulate less specialized human capital and adjust their working time to fit with childcare and household arrangements.

A second view, often called "cultural devaluation," believes that, aside from productivity, perceptions of the differential status that men and women deserve determine wages (e.g., Sørensen 1994; England, Allison, and Wu 2007). The basic idea is that women's work is of lower value than men's work. As a result, occupations that feminize are assigned lower wages because women are thought to deserve lower earnings than men.

A third view highlights conflictual power relations and argues that men are better organized in trade unions and possess more bargaining power than women (Jacobs and Steinberg 1990; Arulampalam, Booth, and Bryan 2007). Unionization is seen as a closure mechanism, by which unions act to accrue higher wages for the incumbents of some occupations. The effect of such a strategy should be higher for craft and operative occupations than service or clerical occupations (Weeden 2002, 89). The rationale for lower pay in female occupations would in this way have less to do with differential perceptions of worth, and rather be that male-dominated occupations are better positioned to garner higher wages.

The aim of our paper is to analyze these competing expectations of the impact that occupational feminization has on wages. Our research tries to advance the literature in two ways. First, our focus is on three West European countriesBritain, Germany, and Switzerland-rather than on the United States. While the influence of occupational feminization on earnings has been repeatedly studied for the United States, only a handful of quantitative studies exists for Europe (de Ruijter [2003] for the Netherlands; Grönlund and Magnusson [2013] for Sweden; Perales [2013] for the UK; Polavieja [2008] for Spain). Our study's comparative design allows us to test whether occupational feminization affects wages similarly across countries-which is uncertain given that the institutional context in which women establish their careers in male-dominated occupations differs substantially across Europe (Le Feuvre 2010). Labor markets with more dispersed wage distributions and less institutional interference, such as the United States and Britain, may feature higher levels of wage devaluation of female occupations than Germany or Switzerland (Mandel and Semyonov 2006).

A second innovation is the study's longitudinal design. We use data stemming from three leading individual-level panel studies: the British Household Panel Survey (BHPS) 1991-2009, the German Socio-Economic Panel (SOEP) 1991-2010, 
and the Swiss Household Panel (SHP) 1999-2011. This design contrasts with the European studies quoted above (except Perales 2013) and several influential American studies (e.g., Sørensen 1994; Tam 1997; Tomaskovic-Devey and Scraggs 2002) that are all based on cross-sectional data. The few existing longitudinal studies for the United States use the National Longitudinal Survey and are thus limited to short timespans and samples of young people (England et al. 1988; Gerhart and El Cheikh 1991; MacPherson and Hirsch 1995). Alternatively, they are set at the aggregate level of occupations, and are thereby unable to control for individual-level differences between workers (Catanzarite 2003; England, Allison, and Wu 2007; Levanon, England, and Allison 2009). The crucial advantage that longitudinal studies have over cross-sectional analyzes is that they enable the researcher to use fixed-effects estimators to control for time-constant unobserved heterogeneity between people. In our case, this allows us to cancel out different ingrained preferences, capabilities, and motivations, which affect both a worker's decision to enter male- or female-dominated occupations, and his or her earnings potential over the life course.

Our paper is structured as follows. Section 2 maps out the theoretical arguments as to why workers in female-dominated occupations should earn lower wages than in male-dominated ones and then details our hypotheses. Section 3 presents our data and estimation method and discusses the advantage of using panel data. Section 4 shows descriptive evidence and the fixed-effects estimations. The concluding section sums up our findings.

\section{Mechanisms Linking Occupational Feminization to Wages}

Empirical research has consistently found that occupations with larger shares of women pay lower wages. The more robust studies use individual-level panel data with fixed effects and focus on the American labor market of the 1970s and 1980s. After controlling for differences in human capital, they find that moving from a completely male to a completely female occupation leads to a wage decrease for women of between 4 (Gerhart and El Cheikh 1991, 69), 8 (England et al. 1988, 554), and 9 percent (MacPherson and Hirsch 1995, 446). For men, the wage penalty for moving out of a completely male into a completely female occupation is somewhat higher and ranges between 9 (MacPherson and Hirsch 1995, 446), 10 (England et al. 1988, 554), and 19 percent (Gerhart and El Cheikh 1991, 69). American panel studies that use occupation instead of the individual as the unit of analysis find that earnings are between 3 to 5 (England, Allison, and Wu 2007, 1250) and 6 to 10 percent (Levanon, England, and Allison $2009,885)$ lower in female-dominated occupations than in mixed-gender occupations, having controlled for skill differences. An American analysis of changes in an occupation's gender composition and wages between 1970 and 2007 finds male earnings to decline by 3 to 5 percent with increasing shares of female entrants, with higher-level occupations being most negatively affected by feminization (Mandel 2013, 1200).

Why should occupations with a majority of female workers pay lower wages than occupations with a majority of male workers? While the debate has introduced several causal mechanisms, the core issue is simple and divides explanations 
into two camps. One camp considers wage disparities between male and female occupations to solely reflect differences in individual human capital and productivity. Gender pay gaps are thus seen as a spurious byproduct of the different endowments and preferences of occupational incumbents. The other camp considers wage disparities to be rooted in perceptions of unequal worth, and therefore points to collective labor-market discrimination against women. The idea is that gendered allocation in the labor market gives way to valuative discrimination, whereby employers tend to undervalue "female" as opposed to "male" work (Petersen and Saporta 2004). In addition, a less prominent but relevant explanation highlights asymetric power resources in the labor market and focuses on differences in collective organization and wage bargaining. ${ }^{1}$

\section{Gender Differences in Job-Specific Skills}

The first camp draws heavily on Gary Becker's (1985, S36) New Home Economics and emphasizes the importance of household specialization among partners. The basic idea is that men specialize in paid work and invest more in job-specific skills, whereas women specialize in childcare and choose mother-friendly occupations that demand less effort and less intensive training. Employers thus pay lower wages in female-dominated occupations because workers' marginal productivity in these occupations is lower than in male-dominated ones. This productivity differential stems from two mechanisms. One mechanism is unequal investment in human capital. Since women, on average, take on more responsibility for childrearing and housework than men, they are more likely to interrupt their employment careers and work part-time than men. This more tenuous attachment to paid work is expected to decrease the incentive for both women to invest in their own-and employers to invest in their female employees'-job-specific human capital (Polavieja 2008, 202; see also Polavieja 2012). Men should thus receive more on-the-job training. The resulting sex differences in job-specific skills and time spent in vocational training are held to be the crucial factor responsible for lower wages in female as opposed to male occupations (Tam 1997, 1656).

Tam (1997) is correct in asserting that male occupations will be more intensive in terms of job-specific vocational training. Vocational education was originally devised to train craftsmen and is thus still more relevant to male-dominated than female-dominated occupations. And although women have surpassed men in graduation rates from upper secondary general educational programs, they are still less likely than men to obtain an upper secondary vocational education (OECD 2012, 53). ${ }^{2}$ For this reason, one underestimates the skill requirements of female occupations by only controlling for job-specific skills and not general skills. ${ }^{3}$

Several implications of this hypothesis can be tested empirically. To begin with, the wage gap between more male- or female-dominated occupations should disappear once we account for differences in jobholders' tenure and on-the-job training. Moreover, on-the-job training is tied to the way a country organizes vocational education - and here our study's comparative setting may prove useful.

Vocational training is highly standardized and embedded in the national educational system in Germany and Switzerland, but acquired to a larger extent through informal on-the-job training in Britain—as in the United States (Charles 
et al. 2001, 376). Job-related training should thus be captured, to some degree, in workers' initial formal educational attainment in Germany and Switzerland's apprenticeship system, but not in the more informal British (and American) system of on-the-job training. Accordingly, job-specific skills should be more consequential for the explanation of sex differences in occupational wages in Britain (and the United States) than in Germany and Switzerland.

\section{Gender Specialization in the Household}

A second mechanism stressed by New Home Economics originates in women's greater investment into domestic work. The idea is that "child care and other housework are tiring and limit access to jobs requiring travel or odd hours" (Becker 1985, S35). Married women and mothers are expected to avoid occupations that make greater demands in terms of constant availability, non-standard hours, overtime work, or business travel. By selecting themselves into less onerous occupations with lower financial rewards, women exchange lower wages for more "familyfriendly" working conditions (Polavieja 2008, 200). Feminizing occupations may become less attractive in terms of wages, but instead offer more predictable work schedules or desirable working hours than male-dominated occupations.

We can again spell out the argument's implications for the empirical analysis. The idea of compensating differentials should apply to women with children, but not to childless women. The moment at which gender specialization should negatively affect women's careers is the birth of the first child (Becker 1985). If household specialization is the key mechanism, it is difficult to see why women without children should be more likely than men to waive earnings in order to get a less demanding, though more comfortable and family-friendly, job. More generally, controls for individual differences in time spent on housework and childcare (investment into the household) and time on overtime work (investment into the job) should explain away any negative effect of the share of women in an occupation.

At the country level, women with children may be more willing (or harder pressed) to forego earnings for family-friendly working conditions if the alternative- the typical full-time job held by men-means very long working hours. In this respect, Switzerland seems to be least family-friendly, with 84 percent of men working 40 hours or more, followed by Germany with 64 percent and Britain with 62 percent. As a consequence, women are more likely to work less than 30 hours per week in Switzerland (46 percent) than in Britain (39 percent) or Germany (38 percent) (OECD family database, data for 2012-13). We find the same rank order in the index of family policy developed by Mandel and Semyonov $(2006,1923)$, where Switzerland is at the very bottom of the distribution, Germany in the lowest fourth, and Britain in the lowest third of twenty-two affluent Western countries. Accordingly, we expect women's investment into domestic work to be more consequential for the gender wage gap in Switzerland than in either Britain or Germany.

\section{Gendered Valuation of Occupations}

Counter to the mechanisms discussed above, sociological theories refute the notion that wages are determined solely by workers' marginal productivity. For Lalive and Stutzer $(2010,936)$, the importance of the bargaining process for 
wage setting strongly suggests that non-economic factors also affect people's earnings. According to the "cultural devaluation" perspective, one such factor is a gender norm that privileges men over women on the labor market and designates more value to male work than female work (England, Allison, and Wu 2007, 1238). A possible mechanism behind gendered valuation is that many female jobs involve care activities-activities that have been recently externalized from the household to the labor-market and still carry the stigma of being closely tied to private household tasks (Bradley 1989).

Lalive and Stutzer $(2010,937)$ review an extensive literature in social psychology, which shows that both women and men consider it appropriate for earnings to be lower for women than men (e.g., Jasso and Webster 1997). Likewise, experimental research consistently finds that women tend to pay themselves lower earnings and ask for less in wage bargaining than do men (e.g., Säve-Söderbergh 2007). A British study finds that women are just as likely to be promoted as men-yet the wage rewards associated with promotion are lower for women than men (Booth, Francesconi, and Frank 2003, 314). Similarly, a Swedish analysis of matched employee-firm data reports that male employees participate to a greater extent in firm profits than female employees (Nekby 2003).

The gendered valuation of occupations and skills makes it difficult to interpret the effect of having children on wages. Men may earn higher wages once they have children, not because they become workaholics and devote more time to their job, but because fatherhood may bestow higher social status on men as the family breadwinner and thereby increase their moral bargaining power in wage negotiations.

It is notoriously difficult to set up an empirical test of the cultural devaluation hypothesis. Traditionally, the existence of cultural devaluation-or active discrimination-has been indirectly inferred from the size of an occupation's sex-composition coefficient, after controlling for differences in workplace characteristics and human capital. We also have to rely on this procedure.

At the country level, the devaluation theory may lead to two opposite expecations. On the one hand, we might expect that in countries with a more egalitarian gender ideology, such as Britain, the process of gender devaluation may be weaker than in the more conservative countries of Germany and, above all, Switzerland. ${ }^{4}$ However, rather than ideology, we expect institutions, and notably the extent of coordination in wage-setting institutions, to be more consequential for the impact that gender devaluation may have on wages. To the extent that the collective bargaining over, and coordination of, wages includes more stakeholders and thus creates a system of checks and balances, wages in occupations may be more closely linked to objectively measurable dimensions of worker productivity-and hence reduce employers' scope for "valuative discrimination" of female work (Petersen and Saporta 2004; Mandel and Semyonov 2006). In this respect, Britain's liberal market economy gives much leeway to employers and single firms, facilitating unilateral management control over wages in most workplaces. In contrast, in Germany's more coordinated market economy, collective agreements at the industry level and powerful works councils at the firm level should limit the extent of gender devaluation. While organized labor is weaker in 
Switzerland than Germany, the extent of coordination in wage bargaining is similar (Soskice 2005). Accordingly, the hypothesis of gendered valuation leads us to expect a greater impact of women's share in an occupation on wages in Britain than in Switzerland and, above all, Germany.

\section{Gender Differences in Power Resources}

Gendered valuation is one explanation for lower wages in female occupations. Another explanation emphasizes different positions of power. Power resources interact with social norms to become highly salient in wage bargaining. Eileen Appelbaum argues that "wages depend largely on the respective bargaining power of business and labor, and on ... normative factors" (in Jacobs and Sternberg 1990, 460). Subordinate groups such as women and minority men are seen as having less political power and thus less leverage to bargain over wages (Catanzarite 2003, 17).

One evident mechanism through which power resources affect wages is trade union representation. Unionization has been identified as a "closure" strategy, by which workers in certain industries and occupations act collectively to use the threat of labor withdrawal in order to maximize their bargaining power (Weeden 2002). Union contracts thereby promote wage levels in covered occupations above those which workers' skills would dictate-a pay premium for power. Again, as with social norms, the effect of differential bargaining power is difficult to capture empirically. One approximation is union membership: union members should benefit from collective bargaining and receive, all else equal, higher wages than nonmembers.

Through their history as organizers of craft and industrial workers, trade unions have traditionally been stronger in male than in female occupations. Male union dominance has waned in some countries as jobs in public services have replaced manufacturing as the primary union stronghold. As of 2002, women's union density rates have consequently surpassed those of men in Britain. Yet, it is not clear that these newer unions are as strong in closing off particular (female) occupations as they were in closing male craft occupations in the past (Weeden 2002, 89). In comparison, Germany's union movement still remains squarely in male hands, with men's union density rate being twice that of women's in the early 2000s (Visser 2011). While data on union density by gender are less systematic in Switzerland, survey evidence suggests that male density rates are 1.6 times those of women's (Oesch 2006, 170). Union membership should be more pertinent in explaining any wage gap between male and female occupations in Germany and Switzerland than in Britain.

\section{Overview of the Hypotheses}

In sum, our study examines four hypotheses of the effect occupational feminization has on wages (see table 1). Hypothesis 1 highlights sex differences in accumulated job-specific skills. It predicts no effect of occupational feminization on earnings once all the standard human capital variables and measures for tenure and on-the-job training have been taken into account. On-the-job training should be particularly consequential for the earnings gap between male and female 
Table 1. Overview of the Hypotheses

\begin{tabular}{|c|c|c|c|c|}
\hline Hypothesis & Focus & Mechanism & $\begin{array}{l}\text { Country } \\
\text { difference }\end{array}$ & $\begin{array}{c}\text { Outcome-Gender } \\
\text { wage gap }\end{array}$ \\
\hline H1 & $\begin{array}{l}\text { Investment } \\
\text { into job- } \\
\text { specific } \\
\text { skills }\end{array}$ & $\begin{array}{l}\text { Disparity in } \\
\text { job-specific skills } \\
\text { explains the wage } \\
\text { gap between } \\
\text { male and female } \\
\text { occupations }\end{array}$ & $\begin{array}{l}\text { Controlling } \\
\text { for on-the-job } \\
\text { training should } \\
\text { decrease wage } \\
\text { gap more in GB } \\
\text { than CH and DE }\end{array}$ & $\begin{array}{l}\text { Productivity- } \\
\text { related: no longer } \\
\text { significant }\end{array}$ \\
\hline $\mathrm{H} 2$ & $\begin{array}{l}\text { Investment } \\
\text { into paid } \\
\text { work and } \\
\text { childcare }\end{array}$ & $\begin{array}{l}\text { Women forego } \\
\text { wages for a } \\
\text { job with more } \\
\text { family-friendly } \\
\text { working } \\
\text { conditions }\end{array}$ & $\begin{array}{l}\text { Controlling } \\
\text { for gendered } \\
\text { investment should } \\
\text { decrease wage gap } \\
\text { more in CH than } \\
\text { DE and GB }\end{array}$ & $\begin{array}{l}\text { Productivity- } \\
\text { related: no longer } \\
\text { significant }\end{array}$ \\
\hline $\mathrm{H} 3$ & $\begin{array}{l}\text { Cultural } \\
\text { devaluation }\end{array}$ & $\begin{array}{l}\text { Gender norms } \\
\text { ascribe higher } \\
\text { value to male } \\
\text { than female work }\end{array}$ & $\begin{array}{l}\text { After controls, } \\
\text { wage gap should } \\
\text { be larger in liberal } \\
\text { than coordinated } \\
\text { countries: in GB } \\
\text { than DE or CH }\end{array}$ & $\begin{array}{l}\text { Discrimination } \\
\text { persists: effect } \\
\text { remains negative }\end{array}$ \\
\hline $\mathrm{H} 4$ & $\begin{array}{l}\text { Power } \\
\text { resources } \\
\text { and union } \\
\text { membership }\end{array}$ & $\begin{array}{l}\text { Male occupations } \\
\text { are more effective } \\
\text { in collective } \\
\text { organization, } \\
\text { where higher } \\
\text { bargaining power } \\
\text { generates pay } \\
\text { premiums }\end{array}$ & $\begin{array}{l}\text { Controlling for } \\
\text { unions should } \\
\text { decrease wage } \\
\text { gap more in } \\
\text { DE than in } \\
\text { CH and GB }\end{array}$ & $\begin{array}{l}\text { Discrimination } \\
\text { persists: effect } \\
\text { remains negative }\end{array}$ \\
\hline
\end{tabular}

occupations in Britain, but less so in Germany and Switzerland, where these skills are, to a larger extent, acquired in formal education.

Hypothesis 2 emphasizes gender differences in housework and expects women to accept lower wages in return for less exacting working conditions. The wage effect of occupational feminization should disappear once we control for women's greater investment into childcare and housework, and men's greater investment into paid work through overtime. This effect should be stronger, the more conservative a country's family policy is-and hence more marked in Switzerland than in Germany and Britain.

Hypothesis 3 focuses on gendered valuation and argues that employers consider female jobs to be inherently less valuable than male jobs. It expects the wage gap between female and male occupations to persist even though differences in human capital, childcare, and housework are accounted for. This wage gap should be larger in liberal market economies, such as Britain, with more unilateral employer control over wages, than in coordinated market economies, such as Germany or Switzerland, where a closer nexus between the educational and wage system makes the occupational wage structure less sensitive to normative pressures. 
Hypothesis 4 highlights the role of power and union membership, and expects unionization to serve as a closure mechanism that operates through collective wage bargaining. Union membership should be a strong mediating factor of the wage gap between women's and men's occupations in Germany, where male occupations have been most successful in leveraging power to achieve pay premiums, and in Switzerland, where unionization is still heavily male, but less so in Britain.

\section{Data, Measures, and Method}

\section{Data}

Our empirical analysis is based on longitudinal data from the British Household Panel (BHPS), the German Socio-Economic Panel (SOEP), and the Swiss Household Panel (SHP). These nationally representative surveys collect information on a wide range of respondents' socio-demographic characteristics and labor-force participation. We draw on unbalanced panels that comprise eighteen waves of data from the BHPS (1991-2009) (Taylor et al. 2010), twenty waves (1991-2010) from the SOEPv27 (Wagner, Frick, and Schupp 2007), and thirteen waves (1999-2011) from the SHP, including booster samples ${ }^{5}$ (Voorpostel et al. 2010).

We restrict our estimations to employees (age twenty-four to legal retirement age $)^{6}$ working 15 hours or more per week. ${ }^{7}$ The self-employed and those in the armed forces, full-time education, or government schemes are excluded, as the wage-setting process of these workers is markedly different. Observations with missing values on relevant covariates are dropped from our analysis. This leaves us with a British sample of 4,700 women and 4,808 men, a German sample with 7,235 women and 8,812 men, and a Swiss sample with 2,147 women and 2,427 men. On average, men appear in a total of twelve years and women in eleven years of the British panel; men in eleven years and women in ten years in the German sample; and men in eight years and women in seven years in the Swiss sample. Each person contributes a minimum of two years (summary statistics for each sample can be found in the Supplementary material online).

\section{Individual and Occupational Measures}

The first decision to be made is how to aggregate over 300 occupations in our three samples. Many of these occupations are empty in some waves and too small in other waves to permit robust wage estimations. Therefore, we group occupations according to the "micro-class" concept introduced by Grusky and Weeden (2001). ${ }^{8}$ This classification combines occupational categories on the basis of their social closure, which is brought about through wage-bargaining processes (unionization), access to training, and returns to education. It provides us with a coherent, cross-nationally comparable measure of eighty-four occupations. One drawback of this classification is the loss of detail in terms of jobs actually performed by men and women-and previous research indicates that the wage effect of occupational feminization is the greater, the finer the job decomposition (Tomaskovic-Devey and Skaggs 2002, 105). 
Our dependent variable is the natural logarithm of individuals' gross monthly wages, expressed in real terms: constant 2005 pounds sterling (for Britain), 2005 euros (for Germany), and 2005 Swiss francs (for Switzerland). ${ }^{9}$ To ensure that potential outliers arising from measurement error do not bias our wage equations, we drop 1 percent of observations at the bottom of the wage distribution.

Our key independent variable is the share of women in a given occupation. This share ranges from 0 to 100 and is calculated for each year on the basis of the Labor Force Survey for Britain (UK-LFS, spring quarter 1991-2008), ${ }^{10}$ the Socio-Economic Panel for Germany (SOEP 1990-2010), and the Swiss Labor Force Survey (SLFS 1998-2011). In order to eliminate spurious variation due to small samples, we average the weighted proportions across two years for Germany and Switzerland. This allows us to calculate the share of women for a given occupation in 1991 by taking the mean proportion of women in 1990 and 1991, and so on.

By taking an annual measure, we address a shortcoming of the few panel studies in the feminization literature. The feminization of occupations implies that shares of women are growing and vary over time. However, in previous longitudinal studies, the share of women in occupations has been measured at one single point in time and therefore kept artificially stable over the observation period (e.g., England 1988; an exception is MacPherson and Hirsch [1995]). This means that fixed-effects analyses are limited to the fraction of workers who change jobs. In not constraining the share of women in an occupation to be the same across years, and observing change over a longer time period, we broaden our scope. This allows us to test the effect of both remaining in a feminizing occupation, and moving from male to female occupations, on a worker's monthly wages.

The highest percentage of workers who move between occupations is observed in our British data, where 67 percent of men $(n=3,217)$ and 63 percent of women $(n=$ $2,959)$ change occupation over the time period 1991-2008. In Germany, this concerns 52 percent of men $(n=4,588)$ and 43 percent of women $(n=3,123)$ for the period 1991-2010. In the shorter Swiss panel (1999-2011), occupational transitions are less numerous, with 27 percent of men $(n=663)$ and 23 percent of women $(n=499)$ changing occupation. Some of the most frequent transitions are from clerical and office occupations to bookkeepers in Britain, or from clerical and office occupations to government officials and nonprofit workers in Germany and Switzerland.

Besides occupational transitions, a second source of variance stems from the changing share of women within an occupation over time. Examples of occupations that were strongly feminizing between the first and last time point are jurists in Britain (1991-2008: +18 percentage points, from 39 to 57 percent), accountants in Germany (1991-2010: +33 p.p., from 10 to 43 percent), or statistical and social scientists in Switzerland (1999-2011: +20 p.p., from 36 to 56 percent). This means that although individuals in our sample experience greater change in the share of women in their occupation when they switch jobs, remaining in a feminizing occupation also contributes substantial variance to our analyses. We control for switching jobs by introducing into our wage equations a dummy $(0 / 1)$ indicating a change in occupation.

The usual determinants in wage equations make up our independent variables: number of hours normally worked per week (delimited to 50 hours), 
current job and firm tenure, part-time status, temporary contract, past unemployment experience, and detailed regional controls. ${ }^{11}$ A series of one-digit industry (NACE), ${ }^{12}$ public sector, and firm size dummies should control for workplace characteristics and pick up industry-specific skills (TomaskovicDevey and Scraggs 2002; Tam 1997).

Good measures for accumulated individual skill and human capital are central to the study of occupational feminization and wages. For all three countries, we construct the same three educational levels (low, intermediary, high) based on the International Standard Classification of Education (ISCED). Work experience in the German models is a measure of total years spent in full-time work, with the exception of those who reported only part-time work experience. Unfortunately, we are forced to approximate work experience using age in the British models. While this is problematic given the differences in spells of inactivity between men and women, previous studies using the BHPS suggest that-once other variables such as tenure are properly controlled for-age serves as a reasonable proxy for work experience (see Bryan and Sevilla-Sanz 2011).

In order to measure occupational differences in general skill requirements, we construct an aggregate measure of an occupation's educational level by averaging the share of people with low (score of 0 ), intermediate (score of 0.5 ), and high education (score of 1). We measure job-skill specialization for Britain and Switzerland by matching from the Labor Force Surveys an occupation's share of incumbents who received any form of training or work-related courses in the reference year. This occupational measure is supplemented by an individual indicator for training received in the reference year of the panel. For Switzerland, as a further test of training-occupation match and to control for unobserved skill specialization that might result from tenure, we include a binary indicator (no $=0$; yes $=1)$ in answer to "Do your qualifications correspond to your job?" The German models contain three precise binary indicators of self-reported job training requirements, coded 1 if a job requires on-the-job training, special courses, or further training, such as technical college.

Differential investment into work and household is captured with variables for unpaid overtime hours per week, marital/cohabiting status, hours spent on housework per week, and the number of dependent children in the household. Hours of housework are capped at 50 hours per week, while unpaid overtime in the main job is originally capped at 23 hours in the German data, and imposed as 28 hours per week for Britain. ${ }^{13}$

Most pertinent to theories of power resources is union coverage at the firm level. The British models test for whether a person's workplace has an established union. For the Swiss SHP, we have information only on individual membership in a work association or a trade union. The same question on union membership was asked in the German SOEP, but only in five waves (1993, 1998, 2001, 2003, 2007). ${ }^{14}$

Occupational feminization is likely to take place in occupations for which there is growing labor demand-and change in labor demand is largely exogenous, driven by technology (Oesch 2013). Since labor demand likely affects the evolution of our key parameters-occupational feminization and wages-we need to control for it. We do so by introducing a measure of the annual share of total 
employment in a given occupation (based on the Labor Force Surveys for Britain and Switzerland, and SOEP for Germany). Over the study period, the annual employment share decreases for occupations such as metal fitters and office clerks, but increases for occupations such as health semiprofessionals and managers.

\section{Model Specification}

In analyzing the effect of occupational feminization on wages, we must address the issue of unobserved heterogeneity. Notably the theories of New Home Economics imply that unmeasured abilities and preferences may explain the negative association between rising shares of women in an occupation and wages. The idea is that women and men select themselves into certain occupations, which carry different wage returns, on the basis of personal attributes not easily observed in survey data. Occupations that are more "female" attract less productive women, who sort into less demanding jobs because they prioritize family care over paid work (MacPherson and Hirsch 1995).

The advantage of fixed-effects panel models is that they eliminate time-invariant, unmeasured characteristics, such as individual preferences, capabilities, and motivations, which can affect wage trajectories (Halaby 2004). The fixed-effects (within) estimator only takes account of the variance stemming from changes in individuals' lives over time, and not differences between individuals. We thus estimate a fixed-effects model that uses individual deviations from person-specific means. The general equation for our linear regressions is given below:

$$
\mathrm{Y}_{\mathrm{it}}=\beta_{0}+\beta_{1} \mathbf{W}_{\mathrm{it}}+\beta_{2} \mathrm{FEM}_{i t}+\beta_{3} \mathrm{H}_{i t}+\gamma_{t+} \boldsymbol{\alpha}_{\mathrm{i}}+\boldsymbol{\varepsilon}_{\mathrm{it}},(\mathrm{t}=1,2, \ldots T),
$$

where $\mathrm{Y}$ is the logarithm of real monthly wages for an individual $i$ in an occupation at time $t$. W is a vector of workplace, regional, occupational, and human capital controls. Our main predictor is a time-varying measure of the share of women in a given occupation, FEM, for individual $i$ at time $t$; $\mathrm{H}$ represents a vector of the timevarying predictors from the hypotheses (JSS, DHI, or Unions), with $\gamma_{t}$ year dummies to condition out wage trends. We remove all time-invariant characteristics that differ between individuals and occupations by allowing $\boldsymbol{\alpha}$ a set of unobserved time-constant variables, to correlate with all of our individual and occupational predictors, where $\boldsymbol{\varepsilon}_{\mathrm{it}}$ represents random error at time $t$ (Allison 2009). The method's limitation is that we cannot eliminate unobserved time-varying characteristics that affect both an occupation's share of women and individual wages.

Regressions are estimated separately for men and women, and we adopt a stepwise approach. The independent variables relevant for each hypothesis are added to our baseline model, and are then removed, to examine net effects. In a second analysis, we test for nonlinear wage effects as an occupation feminizes by decomposing the share of women in an occupation into percentage bands.

\section{Findings on the Wage Effect of Occupational Feminization}

We begin our analysis with descriptive statistics. Figures 1a to 1c show how an occupation's monthly wages vary depending on the share of women in the 
Figure 1. Share of women in an occupation and an occupation's median gross monthly wage

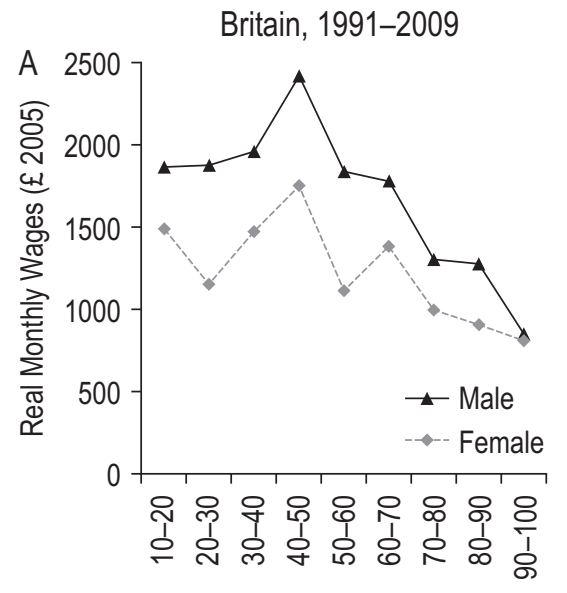

Share of Women in an Occupation (\%)

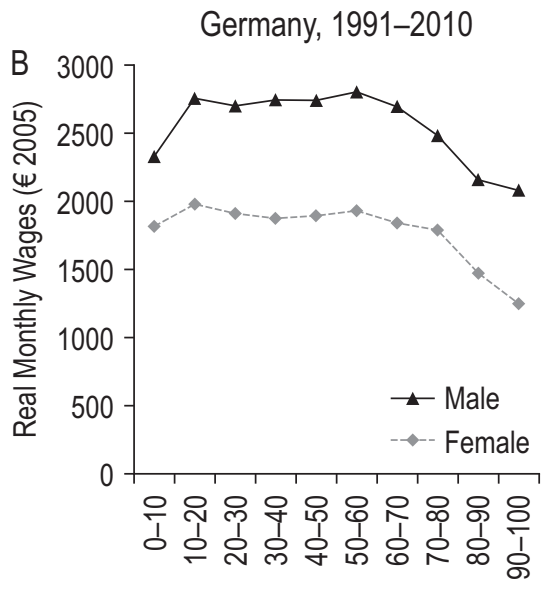

Share of Women in an Occupation (\%)

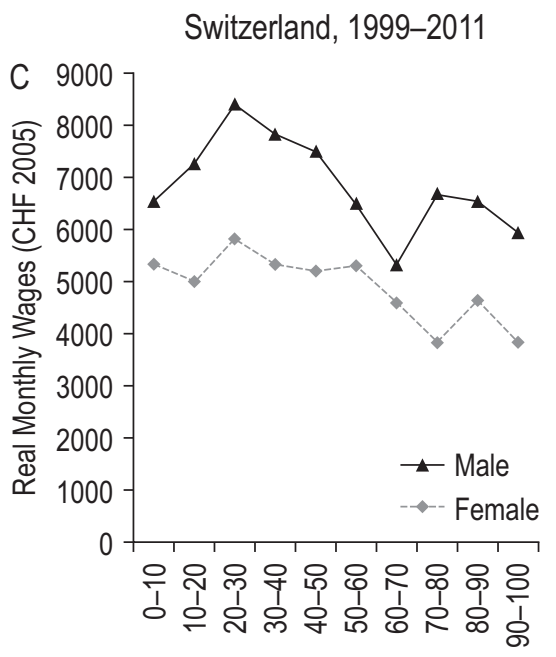

Share of Women in an Occupation (\%)

occupation. Unlike our subsequent multivariate analysis, this computation is set at the aggregate level of occupations and focuses on occupational median wages. Three results are noteworthy.

First, we observe systematically higher median wages for men than women, regardless of the share of women who work in an occupation. The male-female wage gap is largest in occupations holding from 50 to 60 percent women in Britain, 70 to 80 percent women in Switzerland, and 90 to 100 percent women in Germany.

Second, median wage is highest in occupations that employ from 10 to 20 percent of women in Germany, 20 to 30 percent of women in Switzerland, and 40 to 50 percent of women in Britain. Wages then gradually decline as women's 
share in an occupation increases. Female median wages in occupations with a share of 80 to 90 percent women are substantially lower than female median wages in occupations with a share of 30 to 40 percent women-a 38 percent differential in Britain, 21 percent in Germany, and 13 percent in Switzerland. This suggests that wage disparities between male- and female-dominated occupations are higher in Britain than in Germany and, above all, Switzerland.

Third, men's median wages come closest to women's in occupations employing more than 90 percent men, though wages are still higher than at the female end of the occupational distribution. We deal here with mostly low-skilled occupations in production and crafts such as heavy machine operatives or mechanics-and technological change has depressed firms' demand for these jobs over the past few decades (Oesch 2013, Murphy 2014). Lower wage levels in heavily male-dominated occupations suggest that the relationship between shares of women in an occupation and earnings is not linear-a hypothesis to which we return later on.

We move on from descriptive statistics to estimate wage equations for British women and men, German women and men, and Swiss women and men. These analyzes are set at the individual level, and the dependent variable is logged monthly earnings. In a first OLS baseline model M0(OLS), we simply introduce the key independent variable "female share in an occupation" (henceforth FEM), alongside controls for time (in years), normal hours worked per week, and labor demand (the share of employment in a given occupation). In a second baseline model M0(FE), we introduce individual fixed effects alongside the same three control variables. We then keep fixed effects and add, in two subsequent models, controls for workplace characteristics (M1) and standard human capital (M2). The following models (M3 to M5) provide tests of three of our hypotheses: M3 introduces several measures for job-specific skills; M4 includes several variables for household and work investment; and M5 integrates union membership. Finally, M6 provides the results of a full model. For clarity, table 2 shows only the coefficients for our key variable FEM (complete models are found in the appendix; see tables A.1 to A.3).

What are our main findings? The two baseline models (M0) show that removing unobserved heterogeneity makes a considerable difference. For women, the wage penalty of staying in, or moving to, a feminizing occupation is roughly halved when we move from OLS to fixed effects and look only at within-person changes over time. Women who work in female-dominated occupations thus seem to differ from women who work in more male-dominated occupationstheir earnings potential being lower. This doesn't apply to men: men's wage penalty remains the same in Britain, changes from positive to negative in Germany, but is reduced in Switzerland when we use fixed effects.

Both baseline models suggest that moving from a male to a female occupation-or staying within an occupation that feminizes-entails a sizeable wage loss. Adding controls for the workplace (M1) and general human capital (M2) makes no difference: the wage penalty associated with FEM amounts to about 15 percent for British women, British men, and Swiss women, and to about 5 percent for German women, German men, and Swiss men. ${ }^{15}$

The hypothesis that job-specific skills go some way toward explaining why wages are lower in female than in male occupations is supported by our third 


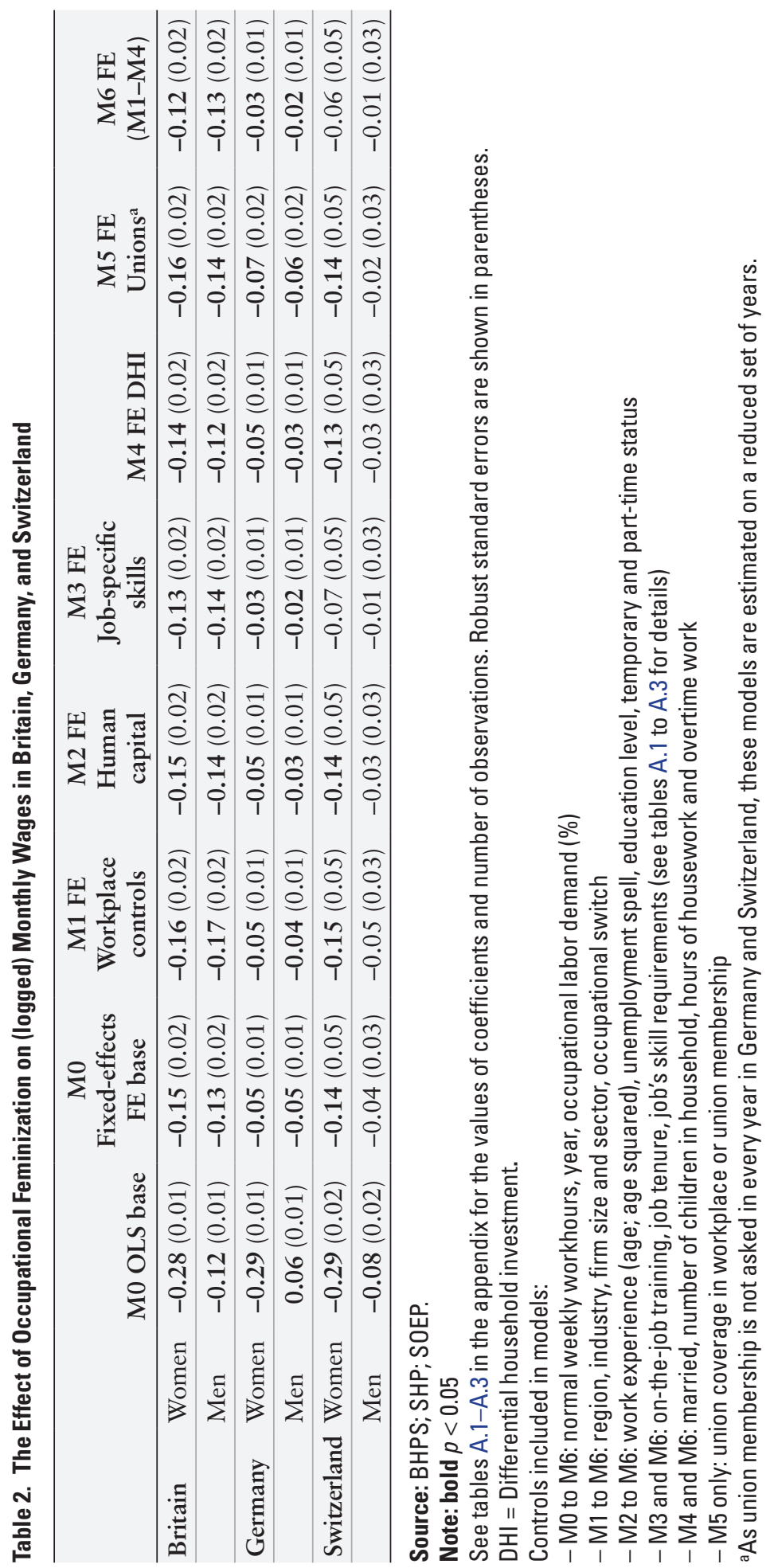


model. Once we introduce controls for job-specific skills (M3), the wage loss associated with moving from a fully male to a fully female occupation remains basically unchanged for British women and men, but becomes substantially smaller for German women and men, and above all, for Swiss women and men. The effect of FEM becomes close to 0 for Swiss men and shrinks from 14 to 7 percent for Swiss women. Differential acquisition in job-specific skills in male and female occupations thus clearly matters. However, the wage penalty associated with FEM does not disappear altogether: all the coefficients remain negative in Germany and Switzerland.

Contrary to our country hypothesis, controlling for job-specific skills does nothing to reduce the massive wage gap between male and female occupations in Britain, but does lead to smaller effects of FEM in Germany and Switzerland. This suggests that in the two German-speaking countries, the acquisition of vocational skills continues over the life course (to a greater extent than in Britain).

The model controlling for differential investment into housework shows that unpaid overtime work on the job is systematically associated, for both men and women, with higher earnings, whereas hours devoted to housework lead to lower earnings. Gender differences emerge with respect to two other characteristics of household upkeep: being married and having dependent children. While marriage increases wages equally for men and women in Britain, its beneficial effect on wages is limited to men in Germany and Switzerland, whereas women seem to lose from it. More marked is the gender difference with respect to children. Even though we control for hours of housework, we still find that having children is associated with lower pay for women in all three countries. Having two or more children in the household entails a substantial decrease in women's wages, from 5 (German women), to 8 (Swiss women) and 9 percent (British women). For men, having children has no negative effect-on the contrary, the coefficients are weak but positive in all three countries.

By and large, we thus obtain the wage effects of overtime, marriage, and children predicted by New Home Economics. However, we do not know whether women's wage penalty, and men's wage bonus, associated with children is due to productivity or discrimination. More importantly, these measures of differential investment into work and the household fail to explain why moving into female occupations is associated with lower wages for men and women. When introducing these measures into the wage equation alongside workplace and human capital controls, the coefficients for FEM remain unchanged in Germany and Switzerland-and they only slightly reduce the (still substantial) wage penalty associated with FEM in Britain. Again, our country hypothesis is not supported. Differential investment in the household does no more to explain away the wage loss associated with FEM in Switzerland, the country with the most conservative family policy, than in Britain or Germany.

Our model M5 incorporates union coverage, or union membership. While we observe a strong positive effect of workplace unions on wages in Britain, union presence does not account for the differences in wages between male and female occupations. In Germany and Switzerland, the wage bonus of union membership is small and statistically significant only for Swiss women. In all three countries, the introduction of union coverage or membership into our wage equation has 
no impact on our key independent variable FEM. Accordingly, we find no evidence for this hypothesis at either the individual or country level.

Finally, when estimating a full model M6, which integrates all of our control variables, we basically obtain the same coefficients for FEM as in model M3, which includes the measures for job-specific skills (alongside workplace characteristics and general humal capital). Crucially, we still observe a wage penalty associated with working in occupations that have high shares of womenalthough we introduce about twenty-five measures for workplace characteristics, general and job-specific human capital, as well as the household. This residual wage penalty is large for British women and men (12-13 percent), non-negligable for Swiss women (6 percent), and small for German women and men (2-3 percent). At this stage, the only hypothesis consistent with this result seems to be gendered valuation: the perception of both employers and employees that male work is more valuable than female work.

However, we further probe the plausibility of Gary Becker's differential investment hypothesis by looking at different subsamples. His argument that women specialize in housework and thus choose less demanding jobs should apply only to women with children-but not to childless women. Specifically, his theory points to the birth of a child as the time at which women's work productivity begins to fall. Women without children seem unlikely to forego higher wages for more family-friendly working conditions. We thus reestimate the full model 6 for a sample that includes only women without children in the household. Since women may make career choices based on planned fertility, their wages potentially decrease a year or two before the first child is born-as they look for a family-friendly job before entering motherhood. For this reason, we limit the

Table 3. The Effect of Occupational Feminization on (logged) Monthly Wages for Women without Children

\begin{tabular}{lcc}
\hline & $\begin{array}{c}\text { M6a FE } \\
\text { Women without children }\end{array}$ & $\begin{array}{c}\text { M6b FE } \\
\text { Women without children at } \\
\text { present and in near future }\end{array}$ \\
\hline Britain & $-0.09(0.02)$ & $-0.09(0.02)$ \\
\hline$n$ individuals & 3,714 & 3,620 \\
\hline Germany & $-0.04(0.02)$ & $-0.04(0.02)$ \\
\hline$n$ individuals & 5,596 & 5,546 \\
\hline Switzerland & & $-0.09(0.05)$ \\
\hline$n$ individuals & $-0.07(0.05)$ & 1,305 \\
\hline
\end{tabular}

Source: BHPS; SHP; SOEP.

Note: bold $p<0.05$

Model M6a excludes women with children in the household (mothers); Model M6b excludes women with children (mothers at present) and women who report a child in the household one to two years later (future mothers). The same controls are included as in model M6 (see table 2 for details). 
samples first to women without children and then further to women without children in the household that remain childless in two subsequent waves of our panels.

The results are shown in table 3 and suggest that, contrary to the expectation of New Home Economics, occupational feminization affects not only the wages of women with children, but also those of childless women. Although the productivity of women without children in the household is not hampered by childcare, the wage penalty associated with FEM is substantial: for childless women, the wage decrease of moving from a completely male occupation to a completely female occupation amounts to 9 percent in Britain, 7 to 9 percent in Switzerland, and 4 percent in Germany.

Next we tackle the question of whether the effect of FEM on wages is linear. Differential valuation of work may become apparent only once an occupation becomes female typed. We examine the existence of a tipping point in FEM's impact on wages by estimating a full model where our continuous variable FEM is decomposed into six bands: less than 30 percent women, 30-40 percent, $40-50$ percent, 50-60 percent, 60-70 percent, and more than 70 percent women in an occupation.

Figure 2 presents the regression coefficients by showing the percentage change in an individual's wage associated with working in male occupations (reference category of $0-30$ percent women in an occupation) to increasingly female occupations. These figures clearly demonstrate that the impact of occupational feminization on wages is not linear, but sets apart occupations holding over a 60 percent share of women. As long as women do not outnumber men in an occupation, it makes little difference for wages whether women's share is 10 or 40 percent in the three

Figure 2. Wage evolution (in \%) from male (0-30\% women) to feminizing occupations-Britain 1991-2009, Germany 1991-2010, Switzerland 1999-2011
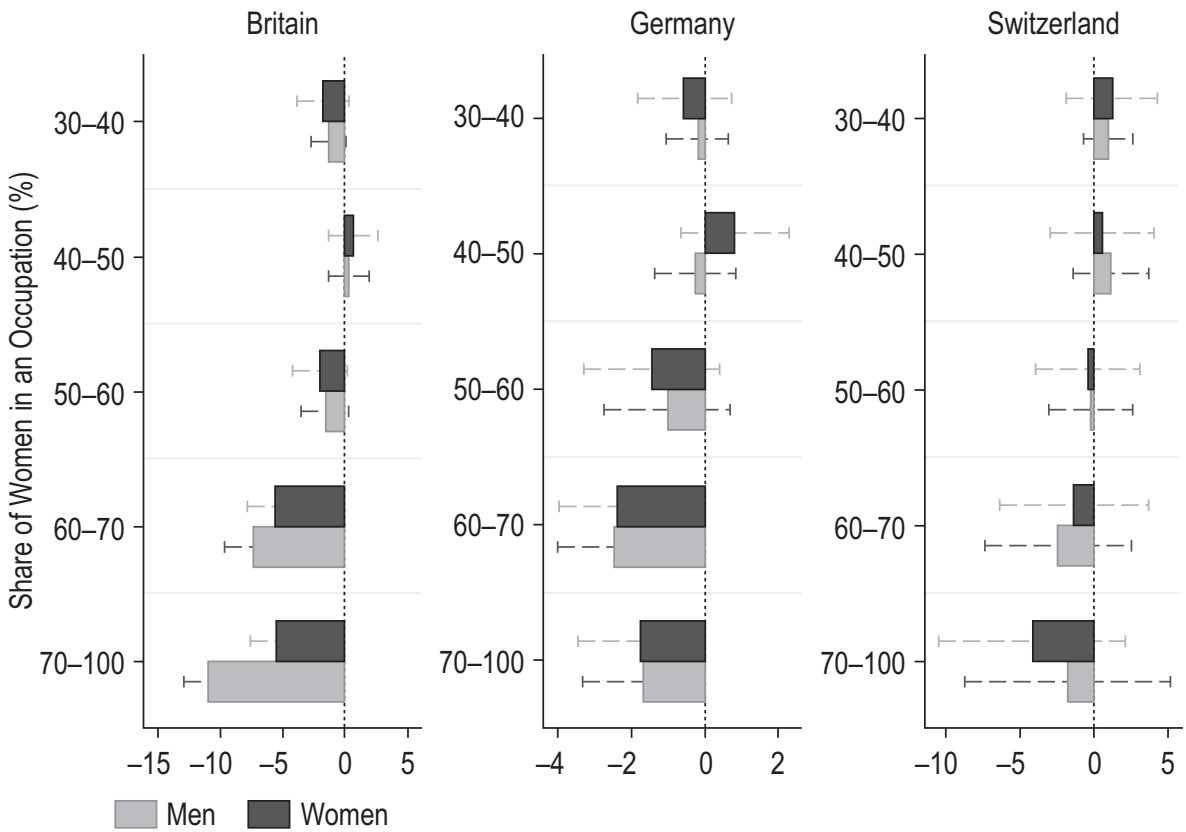
countries under study; the tipping point is reached when an occupation becomes numerically dominated by women, and thereby "female" typified.

Despite introducing all our controls for human capital, job-specific skills, and household investment, the dampening wage effect of FEM apparent in the previous linear regressions is still visible in Britain, Germany, and Switzerland (note that in Switzerland, the sample size is small and the standard errors large, leading to coefficients that are no longer statistically significant). The wage penalty associated with an occupation becoming female typed, at 60 percent FEM, amounts to 5 percent for British women and 2 percent for German men and women. In Britain, the costs of occupational feminization are somewhat higher for men than for women: moving from a male-dominated to an occupation of 60 to 70 percent women entails a wage decline of 7 percent for British men.

While our results strongly suggest that occupational feminization is accompanied by a wage penalty, they leave us to question why we observe a much stronger effect in Britain than in Germany or Switzerland. Our country hypothesis expected a larger scope for gendered valuation-employers' latitude to set wages according to gender perceptions-in countries with a more deregulated wage structure, such as Britain, than in countries with widepread wage coordination, as in Germany or Switzerland. The argument is that it is wage coordination and formal rules-in other words, whether qualifications are closely or loosely tied to the general wage-determination system-rather than specific gender policies that have the strongest impact on women's relative pay position (Rubery et al. 1997). Evidence for this hypothesis is that Germany and Switzerland had consistently lower levels of wage inequality over the 1990s and early 2000s than Britain (OECD 2011, 87). We analyze this hypothesis by replacing monthly wages with individuals' annual wage percentile ranking within each country. ${ }^{16}$ Annual percentile rankings allow us to standardize-and thus cancel out-differences in wage inequality across our three countries.

We reestimate models M0 to M6 with normalized wage percentile ranking as the outcome variable (see table A.4 in the appendix). Although we still find a sizeable wage penalty associated with the share of women in an occupation, country differences do not become smaller. Based on this measure, FEM entails a relative wage loss for Swiss women that is almost as large as for British women and men. As opposed to this, German women, German men, and Swiss men still stand out as being less affected by the share of women in an occupation. Different levels of wage inequality do not directly explain why remaining in, or moving into, a feminizing occupation entails a much larger wage decrease in Britain than in Germany.

Our last step is to analyze whether wage coordination and formal rules decrease employer discretion in setting wages according to their perception of an occupation's worth. We do so by examining the private and public sector separately. The idea is that wage-setting in the public sector adheres more to the logic of formal rules and standard procedures, whereas the private sector gives greater latitude to employers' personal evaluations. We thus estimate a full model M6 on two different subsamples (private/public) where the dependent variable is logged monthly wages and the key independent variable is the share of women in an occupation, decomposed into the same six categories as in figure 2 above. 
The results are shown in figure A.1 in the appendix and reveal that the wage penalty associated with working in a female occupation is systematically larger in the private sector than in the public sector in all three countries. The difference is striking for Germany and Switzerland, where there is a sizeable wage penalty associated with the share of women in an occupation in the private sector, but none in the public sector. On the contrary, coefficients suggest that there is even a small wage bonus associated with FEM in the public sector for men in Germany, and women and men in Switzerland. In Britain, we find a negative effect for FEM in both sectors. The wage penalty, however, is twice as large in the private sector compared to the public sector. This evidence is consistent with the expectations of gendered valuation, and the crucial role the general wage-setting system plays for women's relative pay position.

\section{Conclusion}

This paper opened with the question of whether workers who remain in, or move into, feminizing occupations earn lower wages. A tentative answer from our panel-data analyses is that, in the absence of controls for differences in workplace characteristics and human capital, employment in a completely female occupation is associated with a substantially lower wage than employment in a completely male occupation. This wage penalty amounts to about 15 percent in Britain, Germany, and Switzerland. Once we account for differences in firm characteristics, human capital, and job-specific skills, the effect of occupational feminization on wages becomes more negligible for German women, German men, and Swiss men, but remains substantial for Swiss women and, above all, British women and men. In Britain, workers in an entirely female occupations earn 10 percent lower wages—everything else being equal—than those in entirely male occupations.

Wage disparities between male and female occupations, contrary to the prevailing idea in economics, do not disappear once we control for differences in workers' productivity. Variation in job-specific skills, overtime work, childcare, and housework does not explain why British workers earn lower wages in female, as opposed to male, occupations. Crucially, it is not only women with children, but also childless women and men, who earn lower wages when working in female occupations. In addition, our fixed-effects estimation takes only variation within individuals over time into account. By controlling for time-constant unobserved characteristics, we can discard the hypothesis that our results are driven by the fact that different people (e.g., more productive and ambitious workers) choose to work in different occupations (e.g., male and not female occupations). The implication is that factors beyond productivity must be operating.

Our analysis provides only partial support for the job-specific skill hypothesis-and very little support for the differential investment hypothesis. Likewise, differences in union membership and union coverage cannot explain lower wages in female occupations. Belonging to a union and working in a unionized firm are admittedly imperfect measures of power resources in the labor market, which makes our evidence in this respect tentative at best. 
How can we interpret the failure of these different hypotheses to explain the wage impact of occupational feminization? Our reading of these findings is simple: wage disparities between male and female occupations are, to some extent, rooted in unequal gender norms that accord higher value to male work effort, and thus imply labor-market discrimination against women.

\section{Supplementary Material}

Supplementary material is available at Social Forces online, http://sf.oxfordjournals.org/.

\section{Notes}

1. Another argument that we do not pursue in this paper relates to the crowding of women in a few occupations. The idea is that employer discrimination-or women's own preferences-leads women to seek employment in a few female occupations, resulting in excess supply, which drives down wages (Bergmann 1974; Grönlund and Magnusson 2013).

2. For upper secondary general education, the graduation rates in the OECD were 56 percent for women, but only 44 percent for men in 2010. In contrast, graduation rates from vocational programs were 32 percent for women and 37 percent for men.

3. This point is well demonstrated by England et al. (2000) in their reply to Tam (1997).

4. Note with respect to conservative gender ideology that in Switzerland women's suffrage was introduced, on the national level, only in 1971, gender equality in the constitution only in 1981, and gender equality in matrimonial law only in 1988.

5. We exclude the Northern Ireland sample in the BHPS, and the high-earner sample (G) in SOEP.

6. While the legal retirement age is identical in the three countries for men, it varies for women. Accordingly, our sample consists of men aged 24-64 and women aged 24-59 in Britain, 24-64 for women and men in Germany, and men aged 24-64 and women aged 24-63 in Switzerland.

7. As a sensitivity check, we estimated our regressions excluding those on a part-time contract. This does not substantially alter our results.

8. We benefit from the crosswalks generated by Lambert and Griffiths (2011). These translate three-digit 1990 Standard Occupational Coding (SOC90) indicators in the British data, and four-digit 1988 International Standard Classification of Occupations (ISCO-88) in the Swiss and German data, with minor modifications, into the "microclass" scheme. More information can be found at http://www.geode.stir.ac.uk/.

9. Wages are deflated on the basis of Eurostat's Consumer Price Index (CPI Eurostat index).

10. The years 1991 and 1992 refer to annual data, as the design of data collection began to operate on a quarterly basis only in 1993.

11. Up until 1996 in the SOEP, the question of "contract duration" was asked only of respondents who changed jobs in the reference year. Consequently, we assume constancy across 1991-1995 if no change is reported. Neither an unemployment spell nor a tenure indicator is available for Switzerland. A question on employer tenure was asked only in the first four waves of the SHP, and as a consequence, indicators for tenure are absent in the Swiss models. In our checks for the effect of average occupational tenure (taken from the Swiss Labour Force Survey) in the job-specific skills models, estimates were largely unchanged. 
12. For 2007 in the Swiss data, industrial sector is imputed from the previous year if no changes in employer or job are reported, since the missing data reach 10 percent on this particular item, preventing us from dropping such a large portion of our sample.

13. The question of overtime hours is not asked in the SHP; as a check, we modeled an imperfect proxy calculation for overtime hours on the basis of usual hours minus contractual weekly hours, in addition to an aggregate of the proportion of individuals in an occupation who report 50 or more usual weekly hours. However, none of these measures changed our substantive results and were thus excluded.

14. We are only able to estimate our regressions for union membership on a reduced German sample consisting of five non-consecutive waves. In Switzerland, we exclude the year 2010 from our union models, as union membership was not asked in this wave.

15. Since wages are in log terms, we would need to transform the larger coefficients of our independent variables to obtain precise results; a coefficient of -0.15 for British women thus gives us $1-\exp (0.15)=0.16$; this corresponds to a 16 percent drop in wages.

16. We are grateful to an anonymous reviewer for this suggestion. 


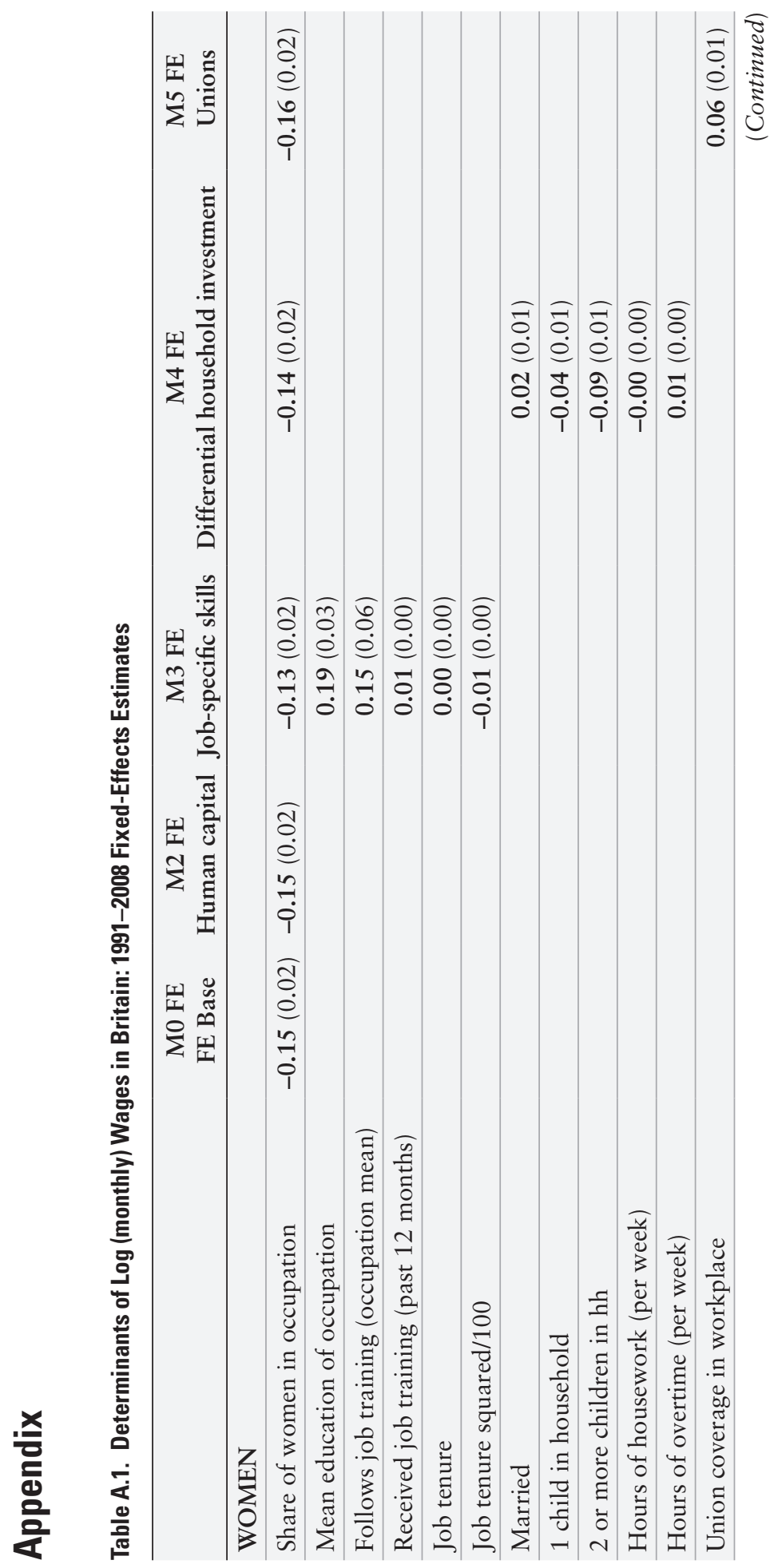




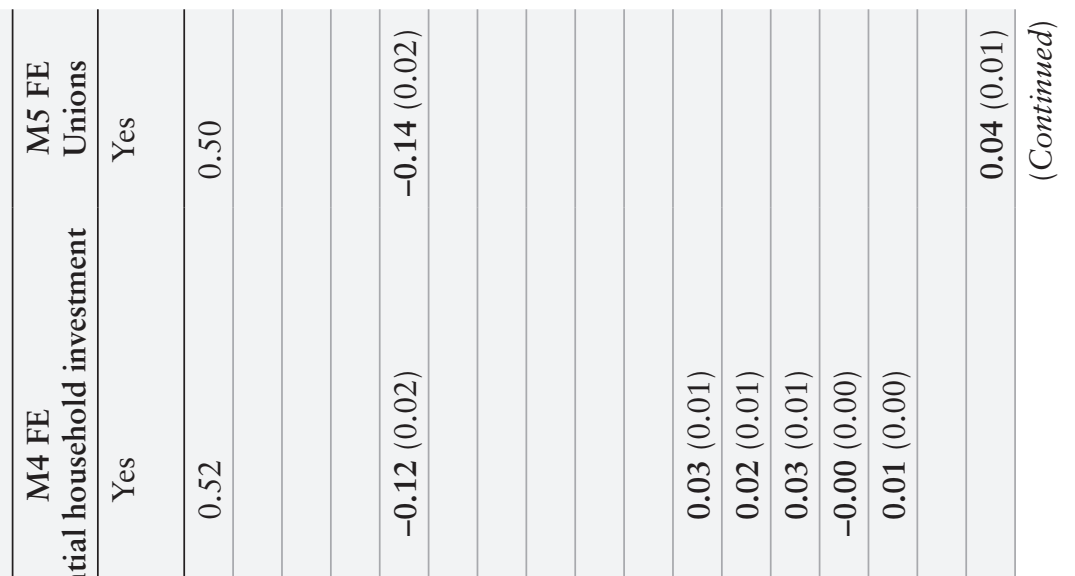

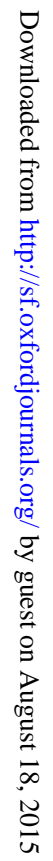

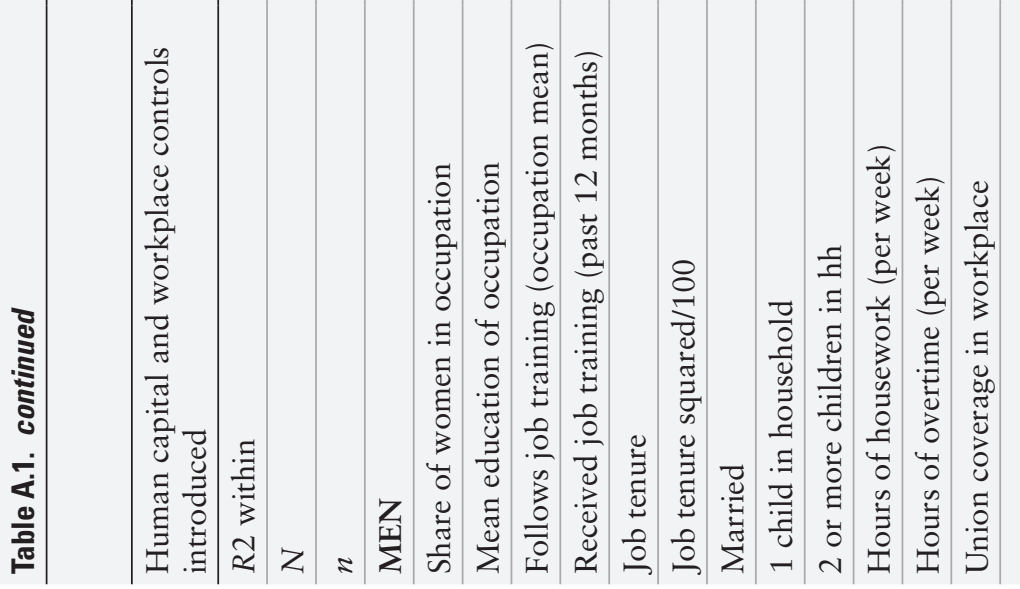




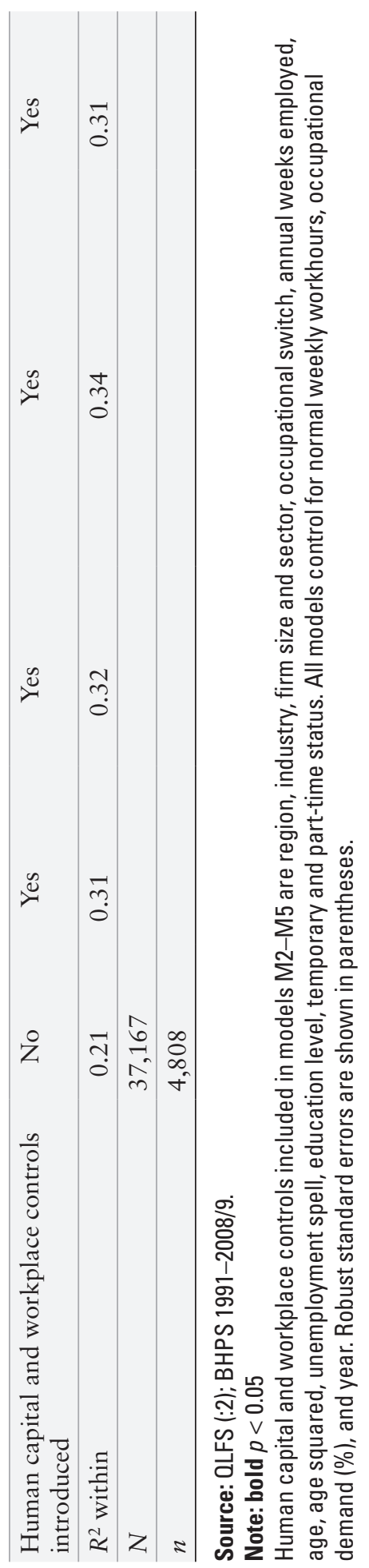




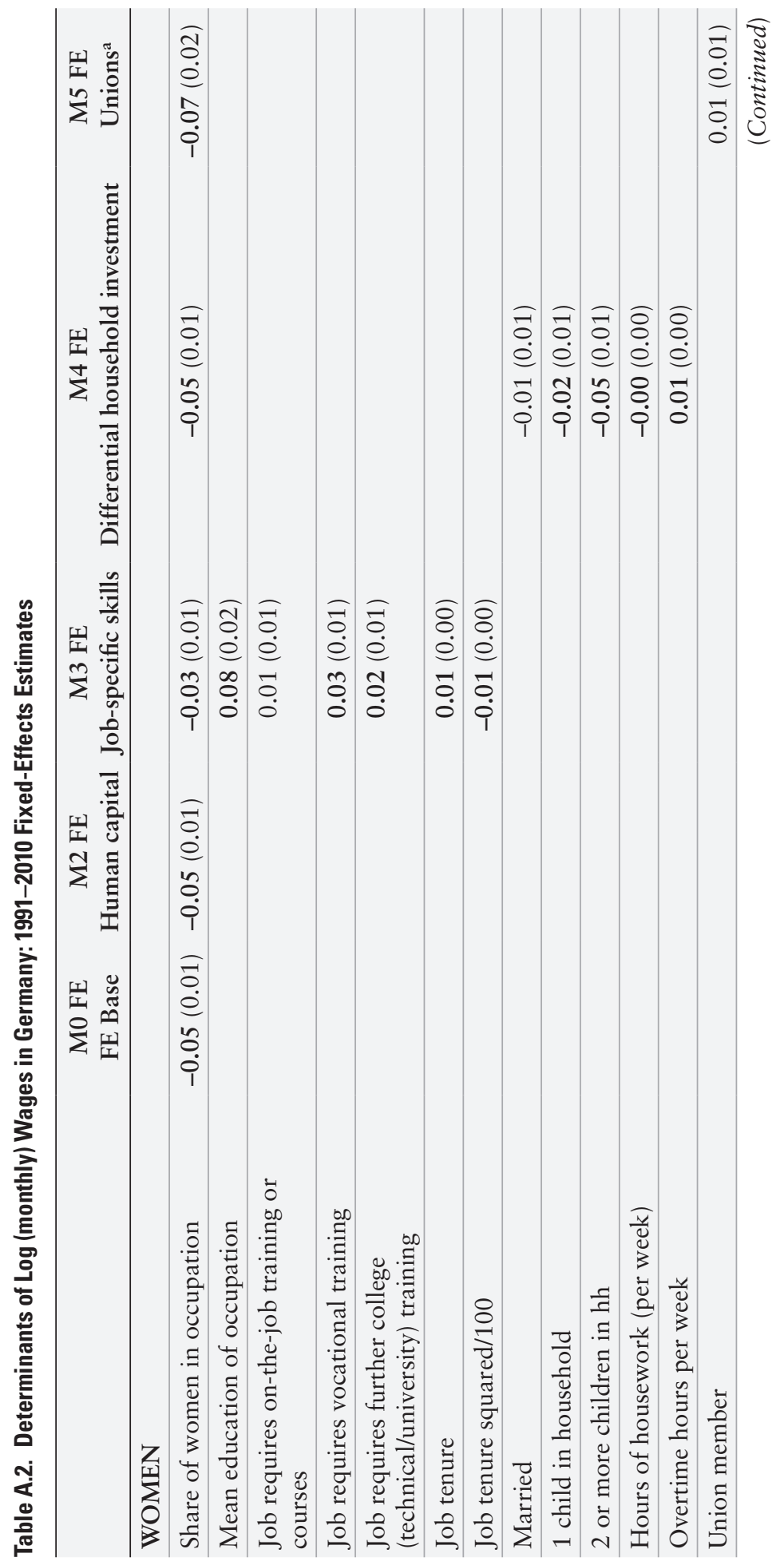

0
0
0
0
0
0
0
0
0
0
0
0
0
0
0
0
0
0
0
0
0
0
0
0
0
0
0
00
0
00
0
0
0
0
0
0
0
0
0
0
$\infty$
0
0
0
0 


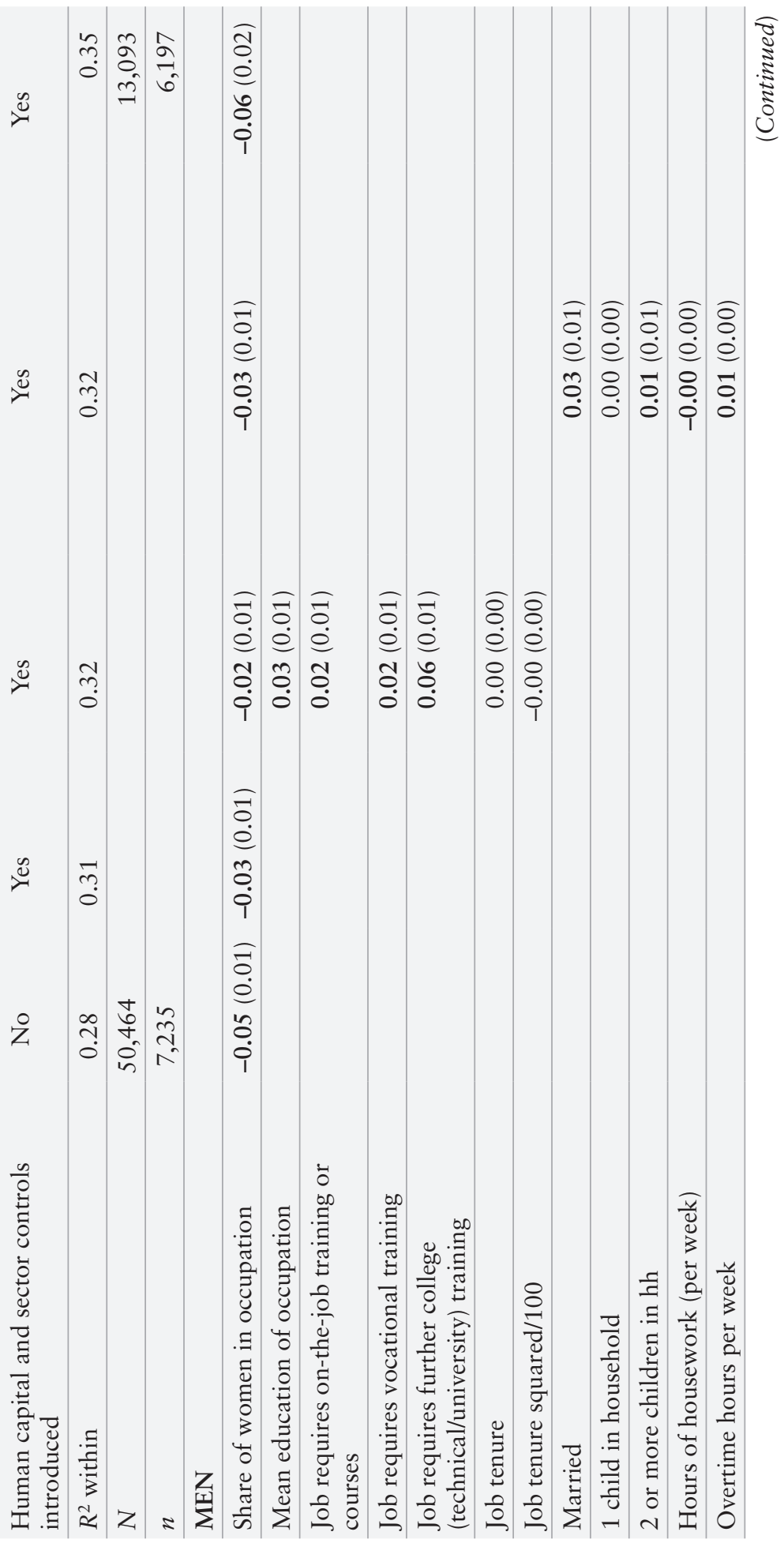




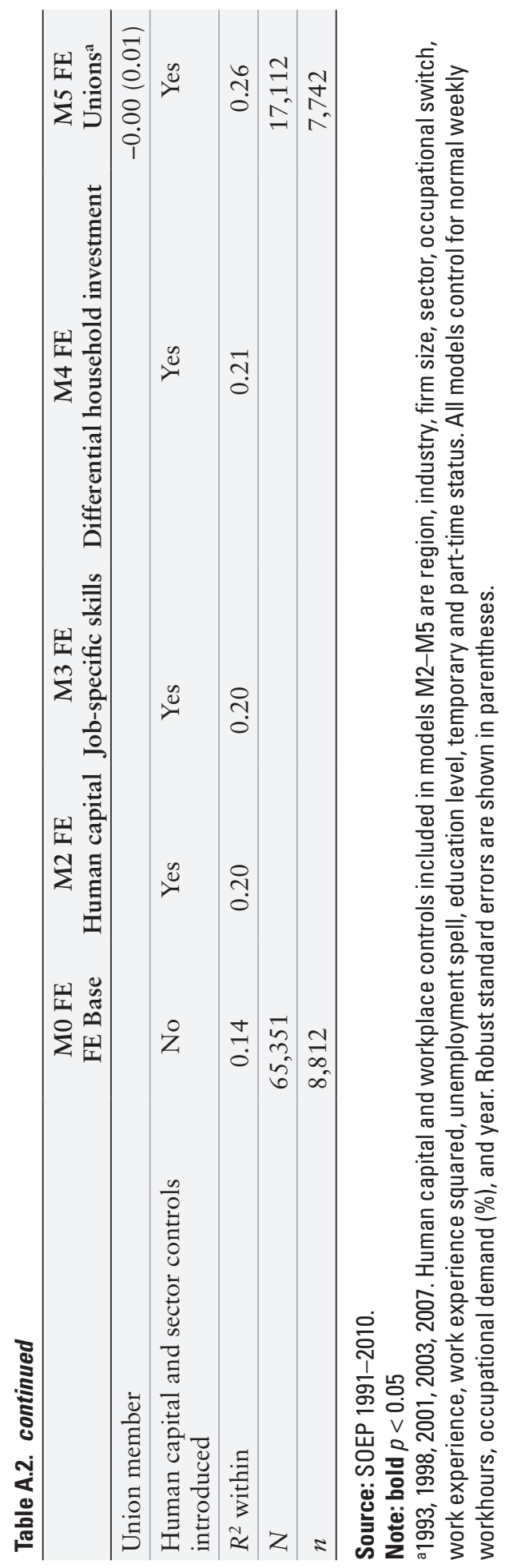




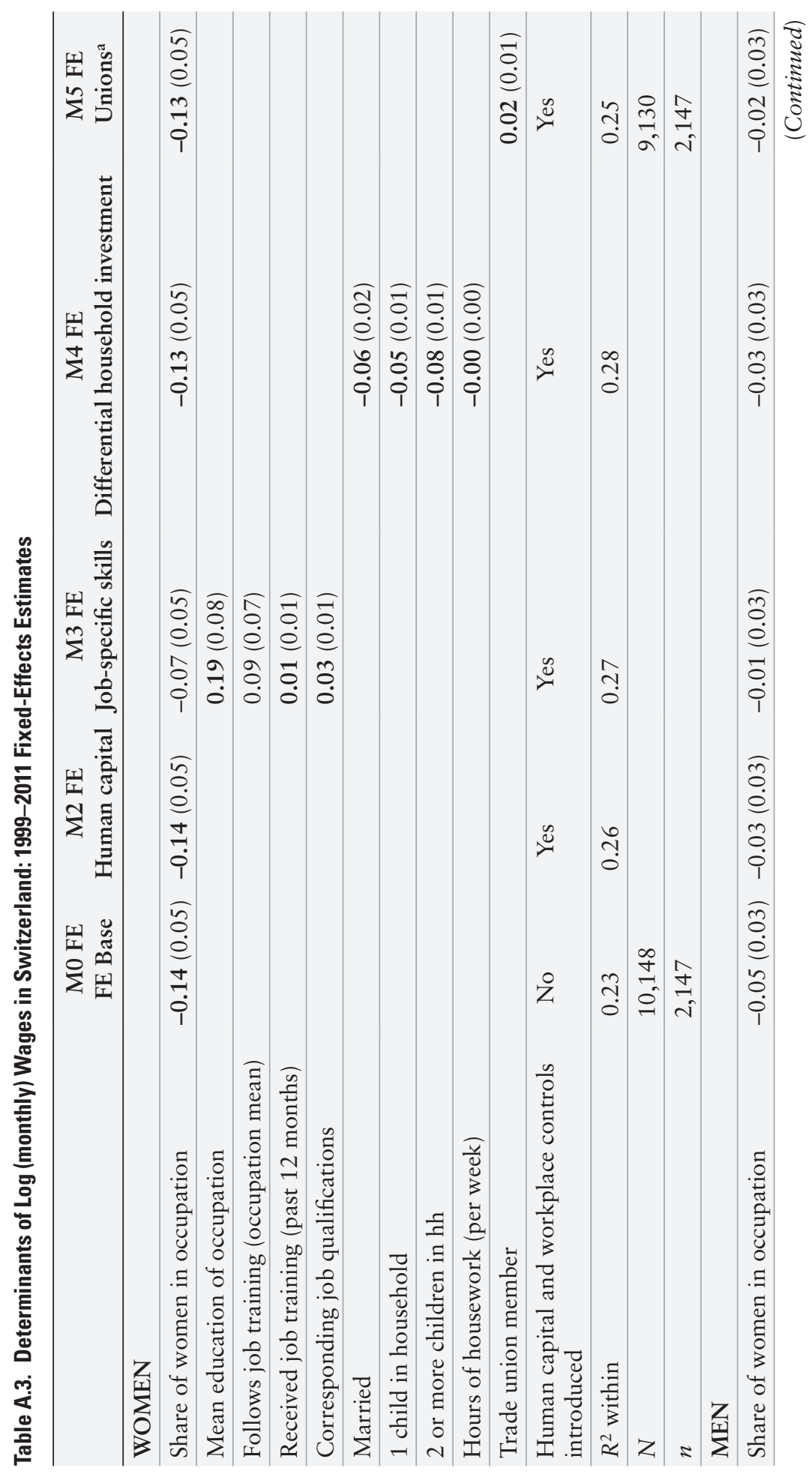

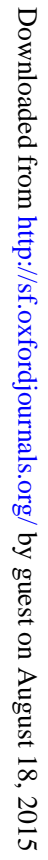




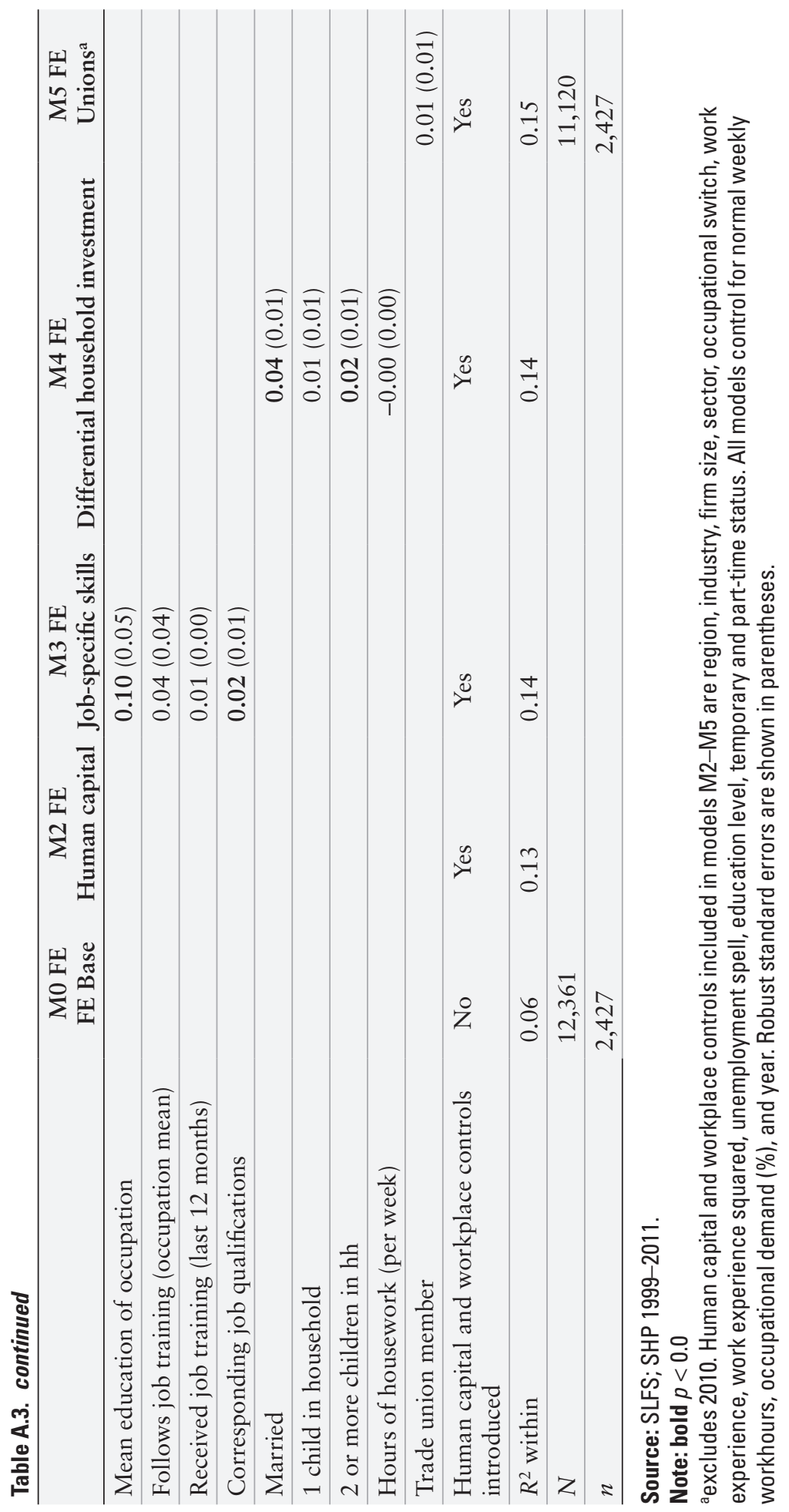




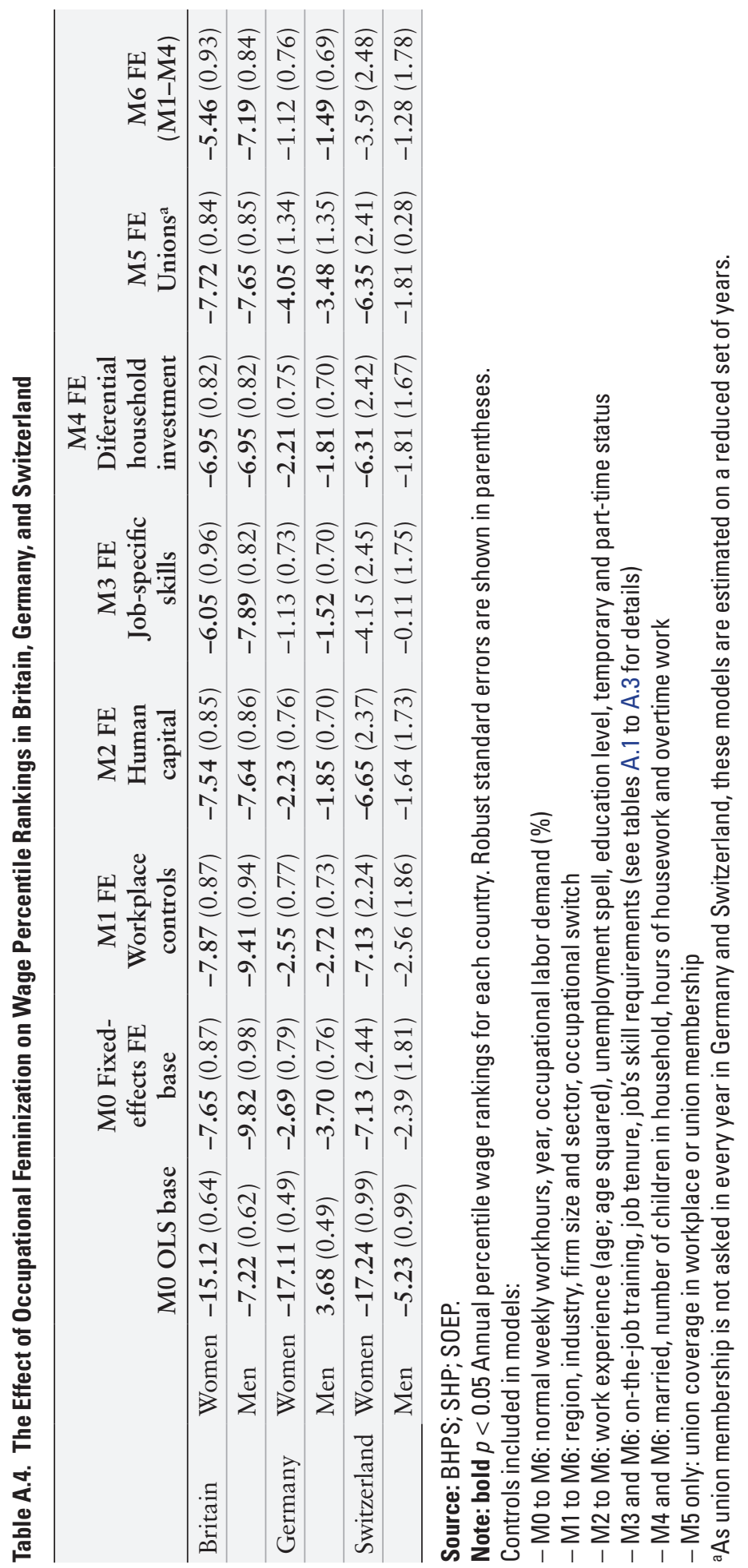




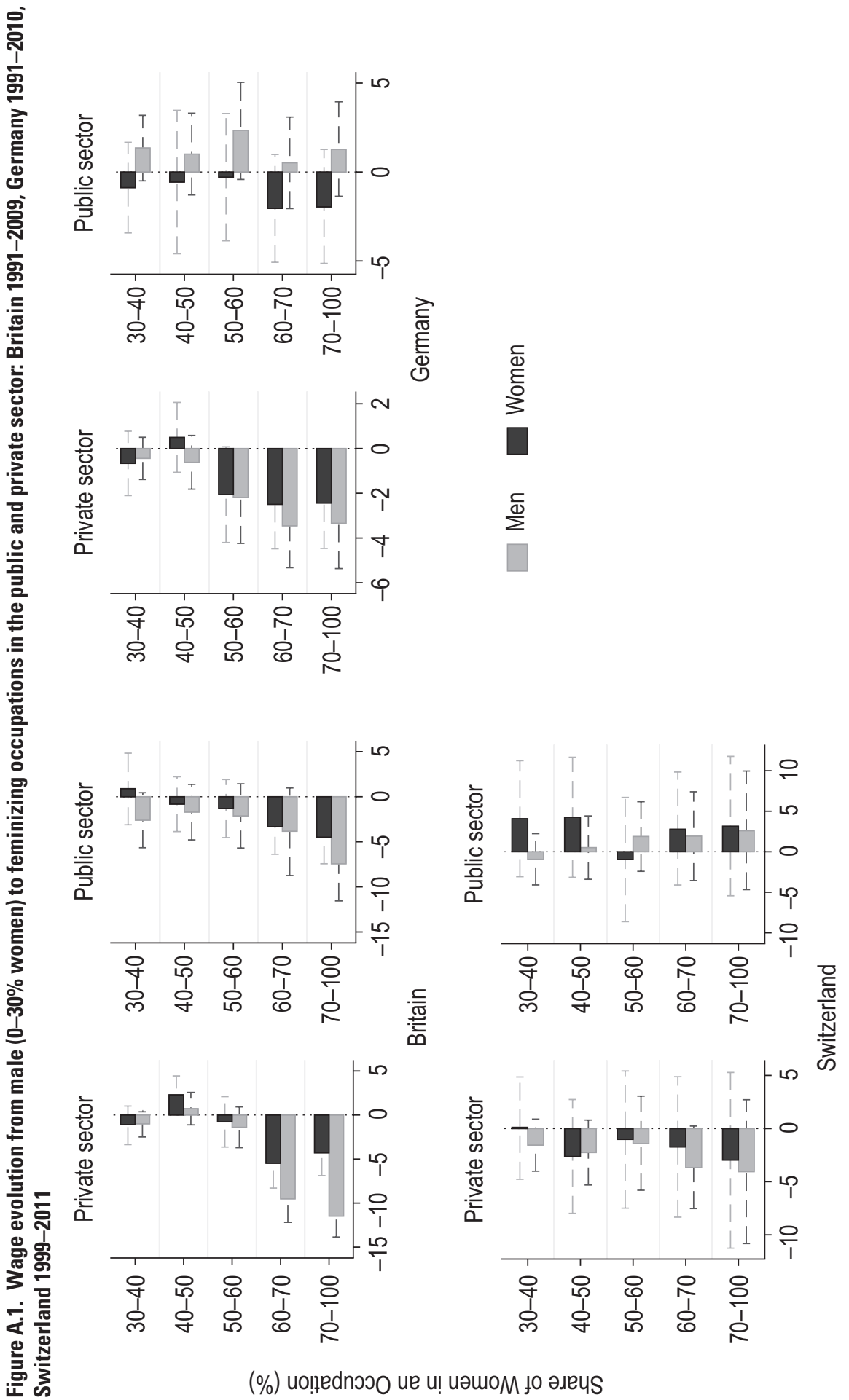




\section{About the Authors}

Emily Murphy received her PhD from the University of Lausanne in 2015 and is a researcher at the Jacobs Center for Productive Youth Development and the Swiss Job Market Monitor (SMM) at the University of Zurich. Her research concentrates on social stratification and occupational mobility, inequality and labor-market mismatch, and parenting and child development.

Daniel Oesch is a professor of economic sociology at the Life Course and Inequality Research Center (LINES) at the University of Lausanne, Switzerland. His research focuses on social stratification and inequality, unemployment, and labor-market policy. He is the author of the two books Redrawing the Class Map (Palgrave Macmillan, 2006) and Occupational Change in Europe (Oxford University Press, 2013).

\section{References}

Allison, P. D. 2009. Fixed Effects Regression Models. Thousand Oaks, CA: SAGE Publications.

Arulampalam, W., A. Booth, and M. Bryan. 2007. "Is There a Glass Ceiling over Europe? Exploring the Gender Pay Gap across the Wage Distribution." Industrial and Labor Relations Review60(2):163-86.

Becker, G. S. 1985. "Human Capital, Effort, and the Sexual Division of Labor." Journal of Labor Economics 3(1):S33-S58.

Bergmann, B. 1974. "Occupational Segregation, Wages, and Profits: When Employers Discriminate by Race or Sex." Eastern Economic Journal 1:103-10.

Booth, A. L., M. Francesconi, and J. Frank. 2003. "A Sticky Floors Model of Promotion, Pay, and Gender." European Economic Review 47:295-322.

Bradley, H. 1989. Men's Work, Women's Work: A Sociological History of the Sexual Division of Labor in Employment. Cambridge, UK: Polity Press.

Bryan, M., and A. Sevilla-Sanz. 2011. "Does Housework Lower Wages? Evidence for Britain." Oxford Economic Papers 63(1):187-210.

Catanzarite, L. 2003. "Race-Gender Composition and Occupational Pay Degredation." Social Problems 50(1):14-37.

Charles, M., M. Buchmann, S. Halebsky, J.M. Powers, and M. M. Smith. 2001. “The Context of Women's Market Careers: A Cross-National Study." Work and Occupations 28(3):371-96.

De Ruijter, J. 2003. "Size and Causes of the Occupational Gender Wage Gap in the Netherlands." European Sociological Review 19(4):345-60.

England, P., P. Allison, and Y. Wu. 2007. “Does Bad Pay Cause Occupations to Feminize, Does Feminization Reduce Pay, and How Can We Tell with Longitudinal Data?" Social Science Research 36(3):1237-56.

England, P., G. Farkas, B.S. Kilbourne, and T. Dou. 1988. "Explaining Occupational Sex Segregation and Wages: Findings from a Model with Fixed Effects." American Sociological Review53(4):544-58.

Gerhart, B., and N. El Cheikh. 1991. "Earnings and Percentage Female: A Longitudinal Study." Industrial Relations: A Journal of Economy and Society 30:62-78.

Grönlund, A., and C. Magnusson. 2013. "Devaluation, Crowding or Skill Specificity? Exploring the Mechanisms behind the Lower Wages in Female Professions." Social Science Research 42(4):1006-17.

Grusky, D., and K. Weeden. 2001. "Decomposition without Death: A Research Agenda for a New Class Analysis." Acta Sociologica 44(3):203-18.

Halaby, C. N. 2004. "Panel Models in Sociological Research: Theory into Practice." Annual Review of Sociology 30(1):507-44.

Jacobs, J., and R. J. Steinberg. 1990. "Compensating Differentials and the Male Female Wage Gap: Evidence from the New York State Comparable Worth Study." Social Forces 69(2):439-68. 
Jasso, G., and M. Webster Jr. 1997. "Double Standards in Just Earnings for Male and Female Workers." Social Psychology Quarterly 60(1):66-78.

Lalive, R., and A. Stutzer. 2010. "Approval of Equal Rights and Gender Differences in Well-Being." Journal of Population Economics 23(3):933-62.

Lambert, P., and D. Griffiths. 2011. "Dimensions and Boundaries: Comparative Analysis of Occupational Structures Using Social Network and Social Interaction Distance Analysis." RC28 paper, http://www. camsis.stir.ac.uk.

Le Feuvre, N. 2010. "Feminising Professions in Britain and France: How Countries Differ." In Gender Inequalities in the 21st Century: New Barriers and Continuing Constraints, edited by Scott, J., R. Crompton, and C. Lyonette, 126-49. Edward Elger Publishing: Cheltenham.

Levanon, A, P. England, and P. Allison. 2009. “Occupational Feminization and Pay: Assessing Causal Dynamics Using 1950-2000 US Census Data." Social Forces 88(December):865-91.

MacPherson, D. A., and B. T. Hirsch. 1995. "Wages and Gender Composition: Why Do Women's Jobs Pay Less?" Journal of Labor Economics 13(3):426-71.

Mandel, H. 2013. "Up the Down Staircase: Women's Upward Mobility and the Wage Penalty for Occupational Feminization, 1970-2007." Social Forces 91(4):1183-207.

Mandel, H., and M. Semyonov. 2006. "A Welfare State Paradox: State Interventions and Women's Employment Opportunities in 22 Countries." American Journal of Sociology 111(6):1910-49.

Murphy, E. 2014. "Workers' Movement Out of Declining Occupations in Great Britain, Germany and Switzerland." European Sociological Review 30(6):685-701.

Nekby, L. 2003. "Gender Differences in Rent Sharing and Its Implications for the Gender Wage Gap, Evidence from Sweden." Economics Letters 81(3):403-10.

OECD. 2011. "Divided We Stand: Why Inequality Keeps Rising." Paris.

OECD. 2012. "Education at a Glance." Paris.

Oesch, D. 2006. Redrawing the Class Map. Stratification and Institutions in Britain, Germany, Sweden and Switzerland. Basingstoke: Palgrave Macmillan.

Oesch, D. 2013. Occupational Change in Europe: How Technology and Education Transform the Job Structure. Oxford: Oxford University Press.

Perales, F. 2013. “Occupational Sex Segregation, Specialized Human Capital, and Wages: Evidence from Britain." Work, Employment \& Society 27(4):600-20.

Petersen, T., and I. Saporta. 2004. "The Opportunity Structure for Discrimination." American Journal of Sociology 109(4):852-901.

Polavieja, J. 2008. "The Effect of Occupational Sex-Composition on Earnings: Job-Specialization, Sex-Role Attitudes, and the Division of Domestic Labor in Spain." European Sociological Review 24(2):199-213. 2012. "Socially Embedded Investments: Explaining Gender Differences in Job-Specific Skills." American Journal of Sociology 118(3):592-634.

Rubery, J., F. Bettio, C. Fagan, F. Maeir, S. Quack, and P. Villa. 1997. "Payment Structures and Gender Pay Differentials: Some Societal Effects." International Journal of Human Resource Management 8(2):131-49.

Säve-Söderbergh, J. 2007. "Are Women Asking for Low Wages? Gender Differences in Wage Bargaining Strategies and Ensuing Bargaining Success." Working Paper, Swedish Institute for Social Research, Stockholm SOFI. http://su.diva-portal.org/smash/record.jsf?pid=diva2:189016.

Sørensen, A. 1994. Comparable Worth: Is It a Worthy Policy? Princeton, NJ: Princeton University Press.

Soskice, D. 2005. "Varieties of Capitalism and Cross-National Gender Differences." Social Politics 12(2):170-79.

Tam, T. 1997. "Sex Segregation and Occupational Gender Inequality in the United States: Devaluation or Specialized Training?" American Journal of Sociology 102(6):1652-92.

Taylor, M. F., J. Brice, N. Buck, and E. Prentice-Lane. 2010. British Household Panel Survey User Manual Volume A: Introduction, Technical Report and Appendices. Colchester: University of Essex. 
Tomaskovic-Devey, D., and S. Skaggs. 2002. "Sex Segregation, Labor Process Organization, and Gender Earnings Inequality." American Journal of Sociology 108(1):102-28.

Visser, J. 2011. "ICTWSS: Database on Institutional Characteristics of Trade Unions, Wage Setting, State Intervention, and Social Pacts in 34 countries between 1960 and 2007." http://www.uva-aias.net/207.

Voorpostel, M., R. Tillmann, F. Lebert, B. Weaver, U. Kuhn, O. Lipps, V.-A. Ryser, F. Schmid, and B. Wernli. 2010. Swiss Household Panel User Guide 1999-2009, Wave 11. Lausanne: FORS.

Wagner, Gert G., Joachim R. Frick, and Jürgen Schupp. 2007. "The German Socio-Economic Panel Study (SOEP): Scope, Evolution, and Enhancements." Schmollers Jahrbuch 127(1):139-69.

Weeden, K. 2002. "Why Do Some Occupations Pay More Than Others? Social Closure and Earnings Inequality in the United States." American Journal of Sociology 108(1):55-101. 